\title{
Source identification of chromium in the sediments of the Xiaoqing River and Laizhou Bay: A chromium stable isotope perspective
}

\author{
Xiaoqing He ${ }^{\text {a, b }}$, Guojun Chen ${ }^{\text {a, c, d }}$, Ziyao Fang ${ }^{\text {a, b }}$, Wenjian Liang a , Boda Li ${ }^{\text {a, e }}$, \\ Jianhui Tang ${ }^{\mathrm{f}}$, Yongge Sun ${ }^{\mathrm{g}}$, Liping Qin ${ }^{\mathrm{a}, \mathrm{b},{ }^{*}}$ \\ ${ }^{a}$ CAS Key Laboratory of Crust-Mantle Materials and Environments, University of Science and Technology of China, Hefei, 230026, PR China \\ ${ }^{\mathrm{b}}$ CAS Center for Excellence in Comparative Planetology, Hefei, 230026, PR China \\ ${ }^{\mathrm{c}}$ Guangdong Key Laboratory of Integrated Agro-Environmental Pollution Control and Management, Guangdong Institute of Eco-Environmental Science and \\ Technology, Guangdong Academy of Sciences, Guangzhou, 510650, PR China \\ d National-Regional Joint Engineering Research Center for Soil Pollution Control and Remediation in South China, Guangzhou, 510650, PR China \\ e Department of Earth, Environmental and Planetary Sciences, Rice University, Houston, TX, 77005, USA \\ ${ }^{\mathrm{f}}$ CAS Key Laboratory of Coastal Environmental Processes and Ecological Remediation, Yantai Institute of Coastal Zone Research (YIC), Chinese Academy of \\ Sciences (CAS) Shandong Key Laboratory of Coastal Environmental Processes, YICCAS, Yantai, 264003, PR China \\ ${ }^{\mathrm{g}}$ Institute of Environment \& Biogeochemistry (eBig), School of Earth Science, Zhejiang University, Hangzhou, 310027, China
}

\section{A R T I C L E I N F O}

\section{Article history:}

Received 30 August 2019

Received in revised form

11 April 2020

Accepted 26 April 2020

Available online 29 April 2020

\section{Keywords:}

Chromium contamination

Chromium isotopes

River sediments

The Xiaoqing River

Leaching experiments

\begin{abstract}
A B S T R A C T
Hexavalent chromium, $\mathrm{Cr}(\mathrm{VI})$, is a heavy metal contaminant and the reduction of $\mathrm{Cr}(\mathrm{VI})$ is accompanied by large isotopic fractionation. In this study, the sources of $\mathrm{Cr}$ were explored using the $\mathrm{Cr}$ isotopic composition of sediments from the Xiaoqing River, a heavily polluted river located in the Shandong Province of China, which flows into Laizhou Bay. The results show that $\delta^{53} \mathrm{Cr}$ values of the sediments are the highest upstream near the pollution source, and gradually decrease along the river toward the range for igneous reservoirs observed near the estuary. Based on the calculation of authigenic $\mathrm{Cr}$ isotopic composition $\left(\delta^{53} \mathrm{Cr}_{\text {auth }}\right)$ using the detrital index and leaching experiments, we suggest that the authigenic $\mathrm{Cr}$ in the sample near the pollution source with the highest $\delta^{53} \mathrm{Cr}_{\text {auth }}$ value mainly comes from the reduction of $\mathrm{Cr}(\mathrm{VI})$ discharged by anthropogenic activity, and authigenic $\mathrm{Cr}$ in other samples in the midstream with $\delta^{53} \mathrm{Cr}_{\text {auth }}$ values slightly higher than the range of igneous reservoirs may come from natural oxidative $\mathrm{Cr}$ weathering products. By introducing a Rayleigh model, we calculate that at least $31 \%$ $-55 \%$ of $\mathrm{Cr}(\mathrm{VI})$ in the river water had been reduced to $\mathrm{Cr}(\mathrm{III})$ near the pollution source. Due to the selfpurification ability of the river, $\mathrm{Cr}(\mathrm{VI})$ was reduced; thus, there is no record of high $\delta^{53} \mathrm{Cr}_{\text {auth }}$ values in the downstream of the Xiaoqing River and Laizhou Bay, indicating no obvious $\mathrm{Cr}$ pollution in these locations. The limited variation of $\delta^{53} \mathrm{Cr}$ values for samples from a sediment core in Laizhou Bay is also indicative of no obvious $\mathrm{Cr}$ pollution in the history. The $\mathrm{Cr}$ isotopic compositions of the river sediments are useful for the identification of $\mathrm{Cr}$ sources and can be used to advise environmental remediation on $\mathrm{Cr}$ pollution.
\end{abstract}

(c) 2020 Published by Elsevier Ltd.

\section{Introduction}

Hexavalent chromium, is a common metal contaminant in natural water systems and mainly comes from mining, leather manufacturing, electroplating, and so on (e.g. Fendorf, 1995; Testa et al., 2004). In surface environments, $\mathrm{Cr}$ exists as either $\mathrm{Cr}$ (III) or

\footnotetext{
* Corresponding author. CAS Key Laboratory of Crust-Mantle Materials and Environments, University of Science and Technology of China, Hefei, 230026, PR China.

E-mail address: lpqin@ustc.edu.cn (L. Qin).
}

$\mathrm{Cr}(\mathrm{VI})$. Oxidized $\mathrm{Cr}(\mathrm{VI})$ always forms ionic groups such as $\mathrm{HCrO}_{4}^{-}$, $\mathrm{CrO}_{4}^{2-}$, and $\mathrm{Cr}_{2} \mathrm{O}_{7}^{2-}$, which are soluble in aqueous fluids and highly toxic. In contrast, the reduced form [ $\mathrm{Cr}(\mathrm{III})]$, as the main valence state in igneous rocks, is less soluble and toxic (Ellis et al., 2002; Johnson and Bullen, 2004; Miretzky and Cirelli, 2010; Wanner et al., 2012). Therefore, the effective way to remediate $\mathrm{Cr}$ pollution is to reduce $\mathrm{Cr}(\mathrm{VI})$ into $\mathrm{Cr}(\mathrm{III})$. The common approach to monitor $\mathrm{Cr}(\mathrm{VI})$ remediation is to determine the $\mathrm{Cr}(\mathrm{VI})$ concentrations in different sites along the transportation path over a long time period. However, this approach cannot resolve whether any observed decrease of $\mathrm{Cr}(\mathrm{VI})$ results from reduction or from dilution, convection, or adsorption (Berna et al., 2010). 
Stable $\mathrm{Cr}$ isotope system is a potential tool for the quantitative determination of $\mathrm{Cr}(\mathrm{VI})$ reduction. Chromium has four stable isotopes: ${ }^{50} \mathrm{Cr}(4.31 \mathrm{wt} \%),{ }^{52} \mathrm{Cr}(83.76 \mathrm{wt} \%),{ }^{53} \mathrm{Cr}$ (9.55 wt\%), and ${ }^{54} \mathrm{Cr}$ (2.38 wt\%). $\mathrm{Cr}(\mathrm{VI})$ reduction by aqueous $\mathrm{Fe}(\mathrm{II}), \mathrm{Fe}(\mathrm{II})$-bearing minerals, organic molecules, or microorganism in sediments and water column is accompanied by $\mathrm{Cr}$ isotopic fractionation, and the reduction degree is quantitatively related to the $\mathrm{Cr}$ isotopic composition of the remaining $\mathrm{Cr}(\mathrm{VI})$ (e.g. Ellis et al., 2002; Kitchen et al., 2012; Sikora et al., 2008). The isotopic fractionation is related to the break of the $\mathrm{Cr}-\mathrm{O}$ bond during $\mathrm{Cr}(\mathrm{VI})$ reduction. Chemical bonds formed by light isotopes have a higher vibration frequency and lower bond energy than those formed by heavier isotopes, so these bonds break more easily, resulting in the enrichment of light isotopes in the products (Schauble et al., 2004). As $\mathrm{Cr}$ (III) is usually insoluble, the remaining $\mathrm{Cr}(\mathrm{VI})$ in the aqueous system will become increasingly heavier. Therefore, $\mathrm{Cr}$ isotopic composition can be used to assess the degree of $\mathrm{Cr}(\mathrm{VI})$ reduction in contaminated groundwater systems (e.g. Berna et al., 2010; Izbicki et al., 2008; Novak et al., 2017). Many previous studies on tracing $\mathrm{Cr}$ pollution with isotope tracers have been conducted for groundwater systems (Berna et al., 2010; Economou-Eliopoulos et al., 2014; Heikoop et al., 2014; Izbicki et al., 2008; Izbicki et al., 2012; Novak et al., 2014; Novak et al., 2017; Raddatz et al., 2010). For instance, Raddatz et al. (2010) used the $\mathrm{Cr}$ isotopic compositions of groundwater to determine if the decrease in $\mathrm{Cr}(\mathrm{VI})$ concentrations resulted from removal via reduction, and Heikoop et al. (2014) found that reduction of $\mathrm{Cr}(\mathrm{VI})$ happened in vadose zone basalts based on $\mathrm{Cr}$ isotopes. However, there are few studies about $\mathrm{Cr}$ isotopic composition in polluted rivers. Surface water is also vulnerable to $\mathrm{Cr}$ pollution. Besides, the $\mathrm{Cr}$ in rivers is more easily subjected to the influence of oxidative chemical weathering than groundwater. Several studies showed that $\delta^{53} \mathrm{Cr}$ values of river water without obvious anthropogenic $\mathrm{Cr}$ pollution range from $-0.2 \%$ to $4.0 \%$ (D'Arcy et al., 2016; Farkaš et al., 2013; Frei et al., 2014; Goring-Harford et al., 2020; Novak et al., 2014; Paulukat et al., 2015; Wu et al., 2017). Frei et al. (2014) found that there is almost no $\mathrm{Cr}$ isotopic variability during the long riverine transport in a subtropical region of South America. The climate is also not a determinant of $\mathrm{Cr}$ isotopic composition during weathering and riverine transport (Wu et al., 2017), instead, the catchment conditions play a major role, e.g. the high $\delta^{53} \mathrm{Cr}$ values are found from stream water flowing through serpentinized ultramafic rocks areas in Czech Republic (Farkaš et al., 2013).

The Xiaoqing River located in Shandong province, eastern China, is one of the most polluted rivers flowing into Laizhou Bay due to industrial development (Heydebreck et al., 2015; Jiang et al., 2017; Zhen et al., 2018). There are some factories (electroplate factory, thermal power plant, steel work and pharmaceutical factory) upstream, which can potentially discharge $\mathrm{Cr}(\mathrm{VI})$ to the river. Therefore, in this work we aimed at identifying the sources of $\mathrm{Cr}$ in the Xiaoqing River based on $\mathrm{Cr}$ isotopes and evaluating the impact of $\mathrm{Cr}$ pollution to Laizhou Bay. Considering the high flow of the river water and irregular discharge, the $\mathrm{Cr}$ pollution in river water may change dramatically over time. Therefore we measured the $\mathrm{Cr}$ isotopic compositions of the river sediments from the upstream to estuary along the Xiaoqing River, which can record the average $\mathrm{Cr}$ pollution signal over a long time period. Besides, the $\mathrm{Cr}$ isotopic compositions of samples from a sediment core in Laizhou Bay were measured to estimate the effect of pollution in history.

\section{Sampling and methods}

\subsection{Sampling}

The Xiaoqing River is one of the major rivers in the central area of Shandong Province, originating from the springs in the city of Jinan. It flows through Licheng, Zhangqiu, Zouping, Gaoqing, Huantai, Boxing, Guangrao, Shouguang and other counties, and finally flows into Laizhou Bay, Bohai Sea. The total length is $237 \mathrm{~km}$ and the drainage area is $10,340 \mathrm{~km}^{2}$ (Zhen et al., 2018). The Xiaoqing River is used to control flooding, irrigation and shipping, but due to the discharge of industrial and sewage waste water, it has become one of the heaviest polluted rivers flowing into Laizhou Bay (Heydebreck et al., 2015; Jiang et al., 2017; Zhen et al., 2018). Twelve surface sediment samples $(0-5 \mathrm{~cm})$ were collected with a stainless steel grab bucket from the upstream region down to the estuary of the river in April 2014 (Fig. 1). Among these samples, sample XQH10 is from a tributary, sample LZW30 is from the estuary, and sample LZW25 is from Laizhou Bay (Fig. 1). There are some factories, especially a electroplate factory near the sample site of XQH1, which can potentially release $\mathrm{Cr}$ contaminant to the river. All the samples were sealed in polyethylene (PE) bags and preserved in a freezer $\left(-20^{\circ} \mathrm{C}\right)$ after sampling. In order to understand the pollution history, a sediment core from Laizhou Bay (the circle outlined in Fig. 1) was collected with a vibratory core sampler in October 2012. The longitude and latitude is $37^{\circ} 29^{\prime} 04.440^{\prime \prime} \mathrm{N}$ and $119^{\circ} 17^{\prime} 25.979^{\prime \prime} \mathrm{E}$, respectively, and the length of the sediment core is $3.3 \mathrm{~m}$. All the samples were dried under natural conditions and were milled to 200 mesh using an agate grinding mortar.

\subsection{Methods}

\subsubsection{Leaching experiments}

Sequential extraction procedures are effective methods to measure trace metal concentrations in different components. Here we followed a modified three-step sequential extraction procedure proposed by the Commission of the European Communities Bureau of Reference (BCR), which had been successfully applied in sediments, soils and sewage sludges (e.g. Ure et al., 1993; Rauret et al., 2000; Žemberyová et al., 2006). The BCR three-step sequential extraction divides the $\mathrm{Cr}$ in sediments into four different forms: exchangeable (extraction Step 1), reducible-iron/manganese oxides (extraction Step 2), oxidizable-organic matter and sulfides (extraction Step 3), and residual Cr (Žemberyová et al., 2006). The standardized procedure of BCR sequential extraction was described in detail in Rauret et al. (2000). Briefly, in the first step, $32 \mathrm{~mL}$ of $0.11 \mathrm{M}$ acetic acid was added to $0.8 \mathrm{~g}$ sediment in a $50 \mathrm{~mL}$ centrifuge tube, and the mixture was shaken in a mechanical shaker for $16 \mathrm{~h}$ at $22 \pm 5{ }^{\circ} \mathrm{C}$ (overnight). Then the reaction product was centrifuged and the supernatant was pipetted into a polyethylene container. The residue was washed by $4 \mathrm{~mL}$ distilled water (twice) and shaken for $15 \mathrm{~min}$. In the second step, $32 \mathrm{~mL}$ of freshly prepared $0.5 \mathrm{M}$ hydroxylammonium chloride $\left(\mathrm{NH}_{2} \mathrm{OH} \cdot \mathrm{HCl}\right)$ (adjusted to $\mathrm{pH} 2-3$ with nitric acid) was added to the residue and shaken in a mechanical shaker for $16 \mathrm{~h}$. The separation method was the same as that described for the first step. The third step was to add $8 \mathrm{~mL}$ high-purity hydrogen peroxide $\left(\mathrm{H}_{2} \mathrm{O}_{2}\right)$ to the residue slowly. The tub was capped loosely and was set at room temperature for $1 \mathrm{~h}$ with occasional manual shaking. Then the tub was capped and heated at $85 \pm 5{ }^{\circ} \mathrm{C}$ for $1 \mathrm{~h}$, with occasional shaking for the first $30 \mathrm{~min}$. The mixture was then dried to less than $3 \mathrm{~mL}$. The mixture was added with another aliquot of $8 \mathrm{~mL} \mathrm{H}_{2} \mathrm{O}_{2}$ and heated at $85 \pm 5^{\circ} \mathrm{C}$ until the volume of liquid was reduced to $\sim 1 \mathrm{~mL} 40 \mathrm{~mL}$ of $1.0 \mathrm{M}$ ammonium acetate $\left(\mathrm{NH}_{4} \mathrm{Ac}\right.$ ) (adjusted to $\mathrm{pH} 2$ with nitric acid) was added to the cool moist residue and shaken for $16 \mathrm{~h}$ at $22 \pm 5{ }^{\circ} \mathrm{C}$. The solution-residue separation step was the same as described above. At the last step, the residue was dried and weighted. About $0.05 \mathrm{~g}$ residue was digested by $1 \mathrm{~mL}$ concentrated $\mathrm{HF}$ and $3 \mathrm{~mL}$ concentrated $\mathrm{HNO}_{3}$ in a Microwave Digestion System (WX-8000). The sample-acid mixtures were heated at $220{ }^{\circ} \mathrm{C}$ until 


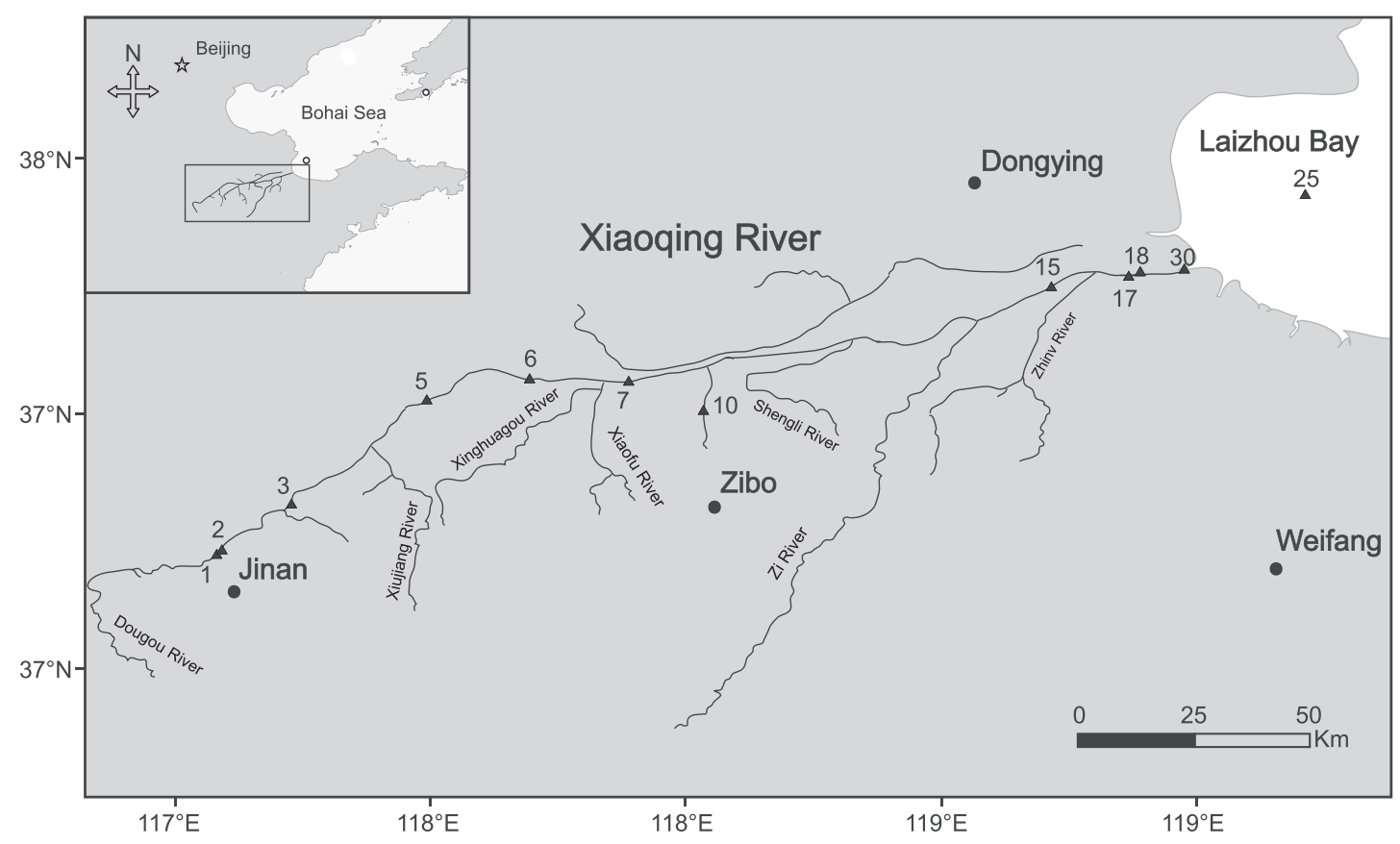

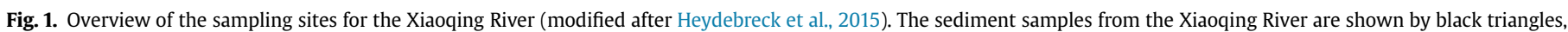
and the sediment core from Laizhou Bay is shown by a circle.

the sample was dissolved completely.

\subsubsection{Major and trace elements analysis}

About $0.05 \mathrm{~g}$ whole-rock sample was digested by $1 \mathrm{~mL}$ concentrated $\mathrm{HF}$ and $3 \mathrm{~mL}$ concentrated $\mathrm{HNO}_{3}$ in a Microwave Digestion System at $220^{\circ} \mathrm{C}$. The major and trace elemental compositions of the whole rocks and leachates were analyzed using iCAP 7200 Inductively Coupled Plasma Optical Emission Spectrometry (ICP-OES) and PerkinElmer Elan DRCII Inductively Coupled Plasma Mass Spectrometry (ICP-MS) at USTC, respectively.

\subsubsection{Cr-isotope analysis}

The detailed $\mathrm{Cr}$ purification procedure was given in Qin et al. (2010) and Shen et al. (2015, 2018). In brief, sample solutions which contained about $1 \mu \mathrm{g}$ Cr were first mixed with ${ }^{50} \mathrm{Cr}-{ }^{54} \mathrm{Cr}$ double spike solution and dried on a hot plate before column chemistry. Then the sample was dissolved in $0.2 \mathrm{~mL}$ of $6 \mathrm{M} \mathrm{HCl}$ and heated at $120-130{ }^{\circ} \mathrm{C}$ for $3 \mathrm{~h}$. The purification of $\mathrm{Cr}$ was accomplished through a two-step cation exchange chromatography procedure with Bio-Rad AG 50-X8 resin (200-400 mesh). The full procedural blank was typically $<10 \mathrm{ng}$ and the yield was $70-90 \%$.

The $\mathrm{Cr}$ isotopic compositions of the whole rocks were measured on a Neptune plus Multi-Collector Inductively Coupled Plasma Mass Spectrometer (MC-ICPMS; Thermo Fisher Scientific, Germany) at USTC. The samples were diluted to $200 \mathrm{ppb}$ in $2 \% \mathrm{HNO}_{3}$ for analysis and were nebulized with an Aridus II desolvator system at an uptake rate of $50 \mu \mathrm{L} \mathrm{min}{ }^{-1}$. All four $\mathrm{Cr}$ isotopes $\left({ }^{50} \mathrm{Cr}^{+},{ }^{52} \mathrm{Cr}^{+}\right.$, ${ }^{53} \mathrm{Cr}^{+}$, and ${ }^{54} \mathrm{Cr}^{+}$), as well as ${ }^{49} \mathrm{Ti}^{+},{ }^{51} \mathrm{~V}^{+}$, and ${ }^{56} \mathrm{Fe}^{+}$(to correct for the interferences from ${ }^{50} \mathrm{Ti}^{+}$and ${ }^{50} \mathrm{~V}^{+}$on ${ }^{50} \mathrm{Cr}^{+}$and from ${ }^{54} \mathrm{Fe}^{+}$on ${ }^{54} \mathrm{Cr}^{+}$), were measured on Faraday cups L2, C, H1, H2, L4, L1, and H4, respectively. Each cup was connected to a $10^{11} \Omega$ resistor. Medium to high mass resolution modes $(5500<\mathrm{M} / \Delta \mathrm{M}<11,000)$ were used to avoid the interferences from polyatomic species such as ${ }^{40} \mathrm{Ar}^{13} \mathrm{~N}^{+},{ }^{40} \mathrm{Ar}^{14} \mathrm{~N}^{+}$, and ${ }^{40} \mathrm{Ar}^{16} \mathrm{O}^{+}$on ${ }^{53} \mathrm{Cr}^{+},{ }^{54} \mathrm{Cr}^{+}$and ${ }^{56} \mathrm{Fe}^{+}$, respectively (Bonnand et al., 2016). A total of 4 blocks with 30 cycles per block were obtained for each analysis. The $\mathrm{Cr}$ isotopic ratios are expressed as the permil variation relative to National Institute of
Standards and Technology (NIST) Standard Reference Material (SRM) 979:

$\delta^{53} \mathrm{Cr}=\left[\frac{\left({ }^{53} \mathrm{Cr} /{ }^{52} \mathrm{Cr}\right)_{\text {sample }}}{\left({ }^{53} \mathrm{Cr} /{ }^{52} \mathrm{Cr}\right)_{\text {SRM } 979}}-1\right] \times 1000 \%$.

Each sequence began with the measurements of the spiked internal $\mathrm{Cr}$ isotope standard SCP (Science, ON, Canada) and NIST SRM 3112a, and the internal standard SCP was analyzed at intervals of four or five samples. Samples were measured once and uncertainties reported here were the largest one among 2 standard error (2SE) of single sample measurement, 2 standard deviations (2SD) of repeated SCP measurements in the same analytical session, and the long-term reproducibility for the standard solution (SCP and NIST SRM 3112a; $0.05 \%$ ). More details of the methods were described in Shen et al. (2018) and Chen et al. (2019a).

The $\mathrm{Cr}$ isotopic compositions of the leachates were analyzed using a Triton plus multi-collector thermal-ionization mass spectrometer (TIMS) at USTC. For these analyses, about $0.1-1 \mu \mathrm{g} \mathrm{Cr}$ was loaded in $3 \mathrm{M} \mathrm{HNO}_{3}$ on outgassed Re filaments with silica gel, saturated boric acid, and aluminum oxide. The rest of the procedure is the same with Shen et al. (2018) and only briefly described here. The standards and samples were measured at ionization temperatures between $1270{ }^{\circ} \mathrm{C}$ and $1390{ }^{\circ} \mathrm{C}$ to avoid possible isobaric interferences at lower or higher ionization temperatures. The $\mathrm{Cr}$ isotope signals $\left({ }^{50} \mathrm{Cr}^{+},{ }^{52} \mathrm{Cr}^{+},{ }^{53} \mathrm{Cr}^{+}\right.$, and ${ }^{54} \mathrm{Cr}^{+}$) were collected on the Faraday detectors L3, L1, axial, and $\mathrm{H} 1$. The typical beam intensity of ${ }^{52} \mathrm{Cr}$ is 3-7 $\mathrm{V}$ measured on $10^{11} \Omega$ amplifiers. To monitor interferences of ${ }^{50} \mathrm{Ti}^{+}$and ${ }^{50} \mathrm{~V}^{+}$on ${ }^{50} \mathrm{Cr}^{+}$and ${ }^{54} \mathrm{Fe}^{+}$on ${ }^{54} \mathrm{Cr}^{+}$, the ionic intensities of ${ }^{49} \mathrm{Ti}^{+},{ }^{51} \mathrm{~V}^{+}$, and ${ }^{56} \mathrm{Fe}^{+}$were measured simultaneously at the Faraday cups L4, L2, and H2, respectively. Each analysis consisted of 200 cycles of isotopic ratios with each cycle integrating the beam intensity for 8.389 seconds. Double spike calculations were performed off-line to correct any mass fractionation during purification and instrumental analysis. Samples were measured twice and uncertainties reported here were the largest one among 
2SE of single sample measurement, 2SD of repeated sample measurements, and the long-term reproducibility for the standard solution (SCP and NIST SRM 3112a; 0.03\%o).

\section{Results}

\subsection{Whole-rock analyses}

Major and trace element concentrations and $\mathrm{Cr}$ isotopic compositions for the surface sediments from Xiaoqing River and Laizhou Bay and the sedimentary core samples from Laizhou Bay are presented in Table S1 and Table 1. The $\mathrm{Cr}$ concentrations in these sediments range from $54 \mathrm{ppm}$ to $485 \mathrm{ppm}$ and the $\delta^{53} \mathrm{Cr}$ values range from $-0.19 \pm 0.05 \%$ to $0.28 \pm 0.05 \%$. The sample $\mathrm{XQH} 1$ from upstream near the electroplate factory has the second-highest $\mathrm{Cr}$ concentration (345 ppm) and the most positive $\delta^{53} \mathrm{Cr}$ value $(0.28 \pm 0.05 \%)$, while the $\mathrm{Cr}$ concentration $(78 \mathrm{ppm})$ in sample $\mathrm{XQH} 2$ which is just $1.2 \mathrm{~km}$ downstream from the sampling location of $\mathrm{XQH} 1$ is considerably lower and the $\delta^{53} \mathrm{Cr}$ value is $0.00 \pm 0.05 \%$ (Figs. 2 and 3). The $\mathrm{Cr}$ concentration in sample $\mathrm{XQH} 3$ is the highest (485 ppm) but its $\delta^{53} \mathrm{Cr}$ value is only $0.03 \pm 0.05 \%$. The $\delta^{53} \mathrm{Cr}$ values of the sediments in the estuary and Laizhou Bay are the lowest, around the average value of igneous reservoirs $(-0.12 \pm 0.10 \%$, 2SD) (Fig. 2) (Schoenberg et al., 2008; Xia et al., 2017), and the sediments from the midstream have intermediate $\delta^{53} \mathrm{Cr}$ values. The trend of $\mathrm{Cr}$ concentrations from midstream to estuary is similar to that of $\delta^{53} \mathrm{Cr}$ values except for sample XQH10. The sample XQH10 comes from a tributary of the Xiaoqing River, and its $\delta^{53} \mathrm{Cr}$ value is higher than those of the samples from the midstream. The $\delta^{53} \mathrm{Cr}$ values of sediment core samples from Laizhou Bay show little variation with depth, all falling within the range of igneous reservoirs.

\subsection{Leaching experiment results}

Chromium in Step 1 and Step 2 contributes a very small proportion to the total $\mathrm{Cr}$ in the samples, which is $0.3-1.1 \%$ and $0.4-2.8 \%$, respectively (Table 2). Most $\mathrm{Cr}$ resides in Step 3 and the residue, which accounts for $5.0-70.7 \%$ and $25.3-111.7 \%$, respectively. The total yield is $97.0-117.4 \%$. The $\mathrm{Cr}$ isotopic compositions of Step 2 of all 8 samples are more positive than the whole rocks, ranging from $0.28 \pm 0.05 \%$ to $1.02 \pm 0.03 \%$, and there is a decreasing trend from upstream to estuary (Fig. 4). The $\delta^{53} \mathrm{Cr}_{\text {Step }} 3$ values of sample $\mathrm{XQH} 1, \mathrm{XQH} 2$, and $\mathrm{XQH} 10$ (0.418 $\pm 0.03 \%$, $0.293 \pm 0.03 \%$, and $0.278 \pm 0.03 \%$, respectively) are obviously

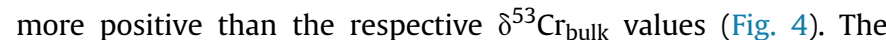

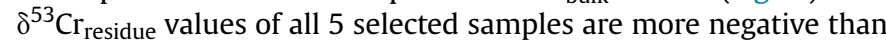
the whole rocks, which lie in the range of igneous reservoirs (Fig. 4).

\section{Discussion}

\subsection{The variations of authigenic $\mathrm{Cr}$ isotopic composition}

In order to understand the influence of riverine transport on $\mathrm{Cr}$ isotopic variations, $\delta^{53} \mathrm{Cr}$ values were plotted as a function of distance from the first sample location near the pollution source area along the main channel (Fig. 3A). The $\delta^{53} \mathrm{Cr}$ value of sample $\mathrm{XQH} 1$ is much more positive than other samples, and $\delta^{53} \mathrm{Cr}$ values decrease with the distance (Fig. 3A). The geological maps (Digital library of National Geological Archives of China; http://ngac.org.cn/ Document/Map.aspx?

MapId=EC7E1A7A7A061954E0430100007F182E) show that most of the overlying rocks in the catchment of the Xiaoqing River are Quaternary clay and sandstone, ruling out the possibility of the influence from serpentinized ultramafic rocks, which are significantly isotopically heavier than major igneous reservoirs (Farkaš et al., 2013; Wang et al., 2016). In addition, the Cr concentration and $\delta^{53} \mathrm{Cr}$ value of sample $\mathrm{XQH} 2$ which is just $1.2 \mathrm{~km}$ away from sample $\mathrm{XQH} 1$ are both low, further excluding the influence from catchment conditions.

Chromium in the river sediments has various sources, including anthropogenic discharge, oxidative chemical weathering and detritus. The detritus portion, which is depleted in ${ }^{53} \mathrm{Cr}$ relative to authigenic $\mathrm{Cr}$ (including the anthropogenic discharge and oxidative chemical weathering here), will suppress the signal from authigenic $\mathrm{Cr}$. Thus, it is necessary to correct the $\mathrm{Cr}$ isotopic compositions of the contribution from the detritus. To date, there are two independent approaches to make such corrections. One method is using a detritus correction index (e.g. Reinhard et al., 2014; Wang et al., 2016). The other method uses the reagents to step-wise leach out the $\mathrm{Cr}$ associated with particular phases. The BCR three-step sequential extraction procedure is widely used on soils and sediments to assess the bioavailable metal fraction and the mobility of trace metals. In this study, both methods were used and the results using the two different methods are compared below.

\subsubsection{The authigenic $\mathrm{Cr}$ isotopic compositions ( $\delta^{53} \mathrm{Cr}_{\text {auth-I }}$ ) calculated using the detrital index}

Titanium is relatively resistant to chemical weathering so that $\mathrm{Ti}$ in sediments is mostly from the detritus (Konhauser et al., 2011).

Table 1

$\mathrm{Cr}$ isotopic compositions for surface sediments and the sedimentary core samples from the Xiaoqing River and Laizhou Bay.

\begin{tabular}{|c|c|c|c|c|c|c|c|}
\hline Sample & Distance (km) & $\mathrm{Cr}(\mathrm{ppm})$ & $\mathrm{Ti}\left(\times 10^{3} \mathrm{ppm}\right)$ & $\mathrm{Cr} / \mathrm{Ti}$ & $\delta^{53} \mathrm{Cr}(\% 0)$ & $\mathrm{N}$ & $\delta^{53} \mathrm{Cr}_{\text {auth-I }}(\% 0)$ \\
\hline $\mathrm{XQH1}$ & 0 & 345 & 2.2 & 0.16 & $0.28 \pm 0.05$ & 1 & $0.35 \pm 0.06$ \\
\hline $\mathrm{XQH} 2$ & 1 & 78 & 1.4 & 0.06 & $0.00 \pm 0.05$ & 1 & $0.09 \pm 0.12$ \\
\hline $\mathrm{XQH3}$ & 20 & 485 & 3.5 & 0.14 & $0.03 \pm 0.05$ & 1 & $0.06 \pm 0.06$ \\
\hline $\mathrm{XQH5}$ & 54 & 198 & 2.4 & 0.08 & $-0.04 \pm 0.05$ & 1 & $0.00 \pm 0.08$ \\
\hline $\mathrm{XQH6}$ & 75 & 171 & 2.3 & 0.07 & $-0.02 \pm 0.05$ & 1 & $0.02 \pm 0.09$ \\
\hline $\mathrm{XQH7}$ & 95 & 135 & 2.2 & 0.06 & $-0.05 \pm 0.05$ & 1 & $0.00 \pm 0.11$ \\
\hline XQH15 & 157 & 137 & 2.3 & 0.06 & $-0.13 \pm 0.05$ & 1 & $-0.13 \pm 0.11$ \\
\hline XQH17 & 173 & 79 & 2.2 & 0.04 & $-0.09 \pm 0.05$ & 1 & $-0.02 \pm 0.27$ \\
\hline XQH18 & 184 & 107 & 2.4 & 0.04 & $-0.10 \pm 0.05$ & 1 & $-0.07 \pm 0.17$ \\
\hline LZW30 & 200 & 54 & 2.1 & 0.03 & $-0.10 \pm 0.05$ & 1 & $0.16 \pm 1.50$ \\
\hline XQH10 & tributary & 68 & 1.1 & 0.06 & $0.10 \pm 0.05$ & 1 & $0.23 \pm 0.11$ \\
\hline LZW25 & Laizhou Bay & 56 & 2.1 & 0.03 & $-0.07 \pm 0.05$ & 1 & $0.45 \pm 1.28$ \\
\hline LZWcore-9 & & 73 & 3.2 & 0.02 & $-0.14 \pm 0.05$ & 1 & \\
\hline LZWcore-17 & & 67 & 2.8 & 0.02 & $-0.19 \pm 0.05$ & 1 & \\
\hline LZWcore-25 & & 58 & 2.4 & 0.02 & $-0.11 \pm 0.05$ & 1 & \\
\hline LZWcore-33 & & 72 & 3.2 & 0.02 & $-0.13 \pm 0.05$ & 1 & \\
\hline LZWcore-126 & & 58 & 2.8 & 0.02 & $-0.18 \pm 0.05$ & 1 & \\
\hline
\end{tabular}




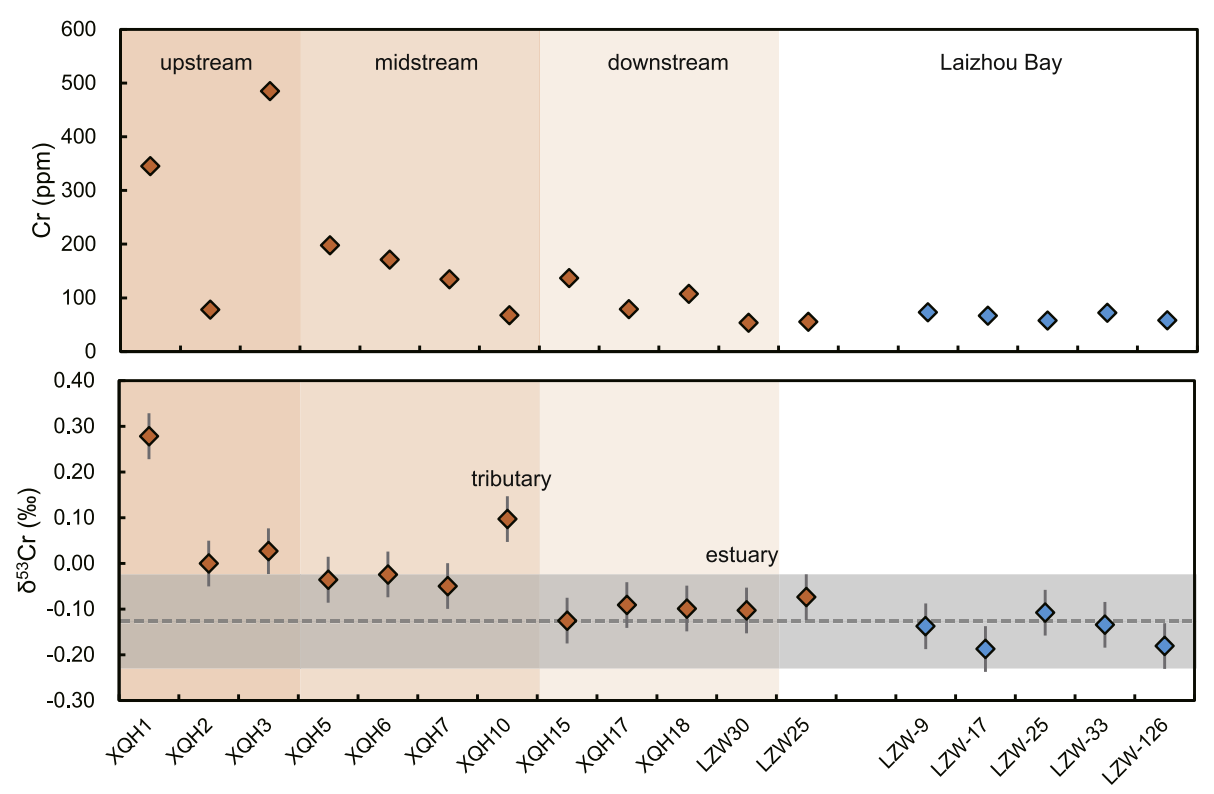

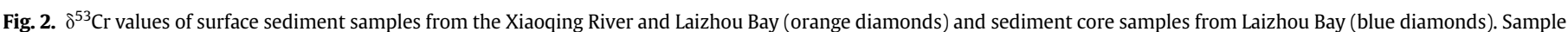

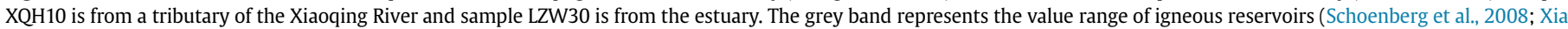

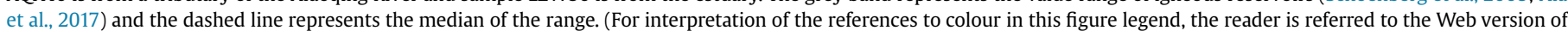
this article.)
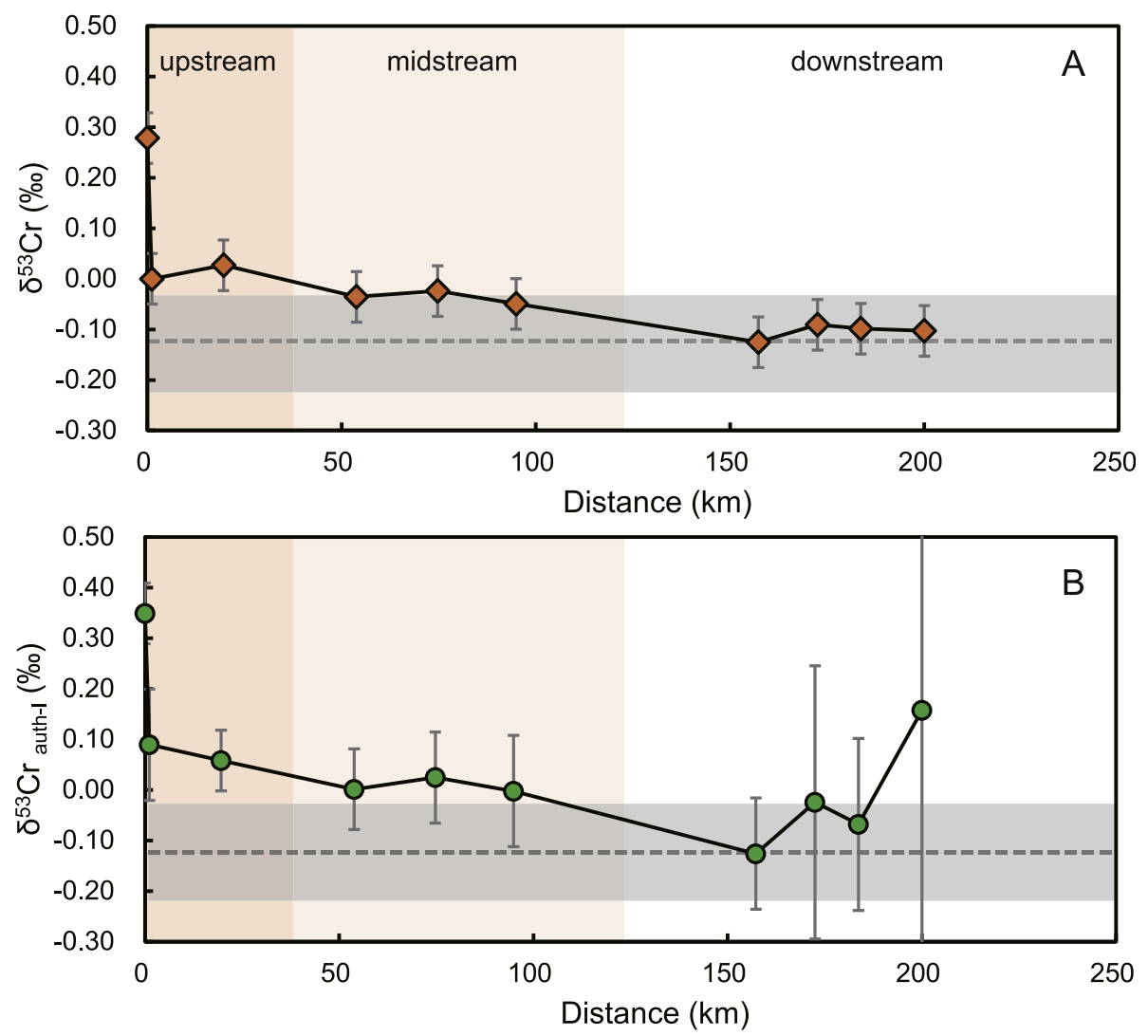

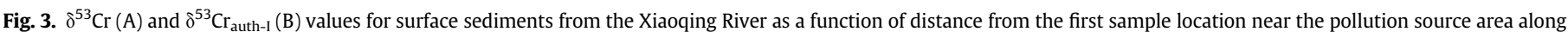

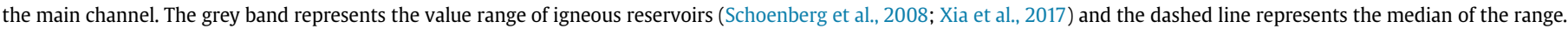

Therefore, Ti concentration in the sediments can serve as an index of the detrital contribution in order to estimate the concentration of detrital $\mathrm{Cr}$, which is then used to calculate the authigenic $\mathrm{Cr}$ isotopic composition $\left(\delta^{53} \mathrm{Cr}_{\text {auth-I }}\right)$. Titanium has a close correlation with $\mathrm{Al}$ and $\mathrm{Th}$, which are also identified as indexes of the detrital contribution (Fig. S1). The correction for detrital $\mathrm{Cr}$ is made using the 
Table 2

$\mathrm{Cr}$ isotopic compositions of four $\mathrm{Cr}$ forms for the selected samples from the Xiaoqing River and Laizhou Bay.

\begin{tabular}{|c|c|c|c|c|c|c|c|c|c|c|c|c|}
\hline Sample & Step $1(\%)$ & Step $2(\%)$ & $\delta^{53} \mathrm{Cr}_{\text {Step 2 }}(\% 0)$ & $\mathrm{N}$ & Step $3(\%)$ & $\delta^{53} \mathrm{Cr}_{\text {Step } 3}(\% 0)$ & $\mathrm{N}$ & Residue (\%) & $\delta^{53} \mathrm{Cr}_{\text {residue }}(\% 0)$ & $\mathrm{N}$ & Yield (\%) & $\delta^{53} \mathrm{Cr}_{\text {auth-II }}(\% 0)$ \\
\hline $\mathrm{XQH} 1$ & 0.5 & 0.6 & $1.02 \pm 0.03$ & 2 & 70.6 & $0.42 \pm 0.03$ & 2 & 25.3 & $-0.04 \pm 0.03$ & 2 & 97.0 & $0.42 \pm 0.03$ \\
\hline $\mathrm{XQH} 2$ & 0.8 & 1.1 & $0.78 \pm 0.03$ & 2 & 37.6 & $0.29 \pm 0.03$ & 2 & 75.7 & $-0.17 \pm 0.03$ & 2 & 115.2 & $0.31 \pm 0.03$ \\
\hline $\mathrm{XQH3}$ & 0.5 & 1.0 & $0.78 \pm 0.03$ & 2 & 70.7 & $0.07 \pm 0.03$ & 2 & 35.0 & $-0.12 \pm 0.03$ & 2 & 107.3 & $0.08 \pm 0.03$ \\
\hline XQH6 & 1.0 & 2.8 & $0.48 \pm 0.03$ & 2 & 64.4 & $-0.01 \pm 0.03$ & 2 & 47.4 & & & 115.6 & $0.01 \pm 0.03$ \\
\hline XQH10 & 0.5 & 0.7 & $0.51 \pm 0.03$ & 2 & 53.5 & $0.28 \pm 0.03$ & 2 & 53.6 & $-0.06 \pm 0.03$ & 2 & 108.4 & $0.28 \pm 0.03$ \\
\hline XQH15 & 0.7 & 1.6 & $0.51 \pm 0.03$ & 2 & 45.9 & $-0.22 \pm 0.03$ & 2 & 50.3 & & & 98.5 & $-0.19 \pm 0.03$ \\
\hline LZW30 & 1.1 & 2.5 & $0.28 \pm 0.05$ & 3 & 23.7 & $-0.12 \pm 0.03$ & 2 & 94.8 & $-0.12 \pm 0.03$ & 2 & 122.0 & $-0.09 \pm 0.03$ \\
\hline LZWcore-33 & 0.3 & 0.4 & $0.38 \pm 0.03$ & 2 & 5.0 & $-0.21 \pm 0.03$ & 2 & 111.7 & & & 117.4 & $-0.16 \pm 0.03$ \\
\hline
\end{tabular}

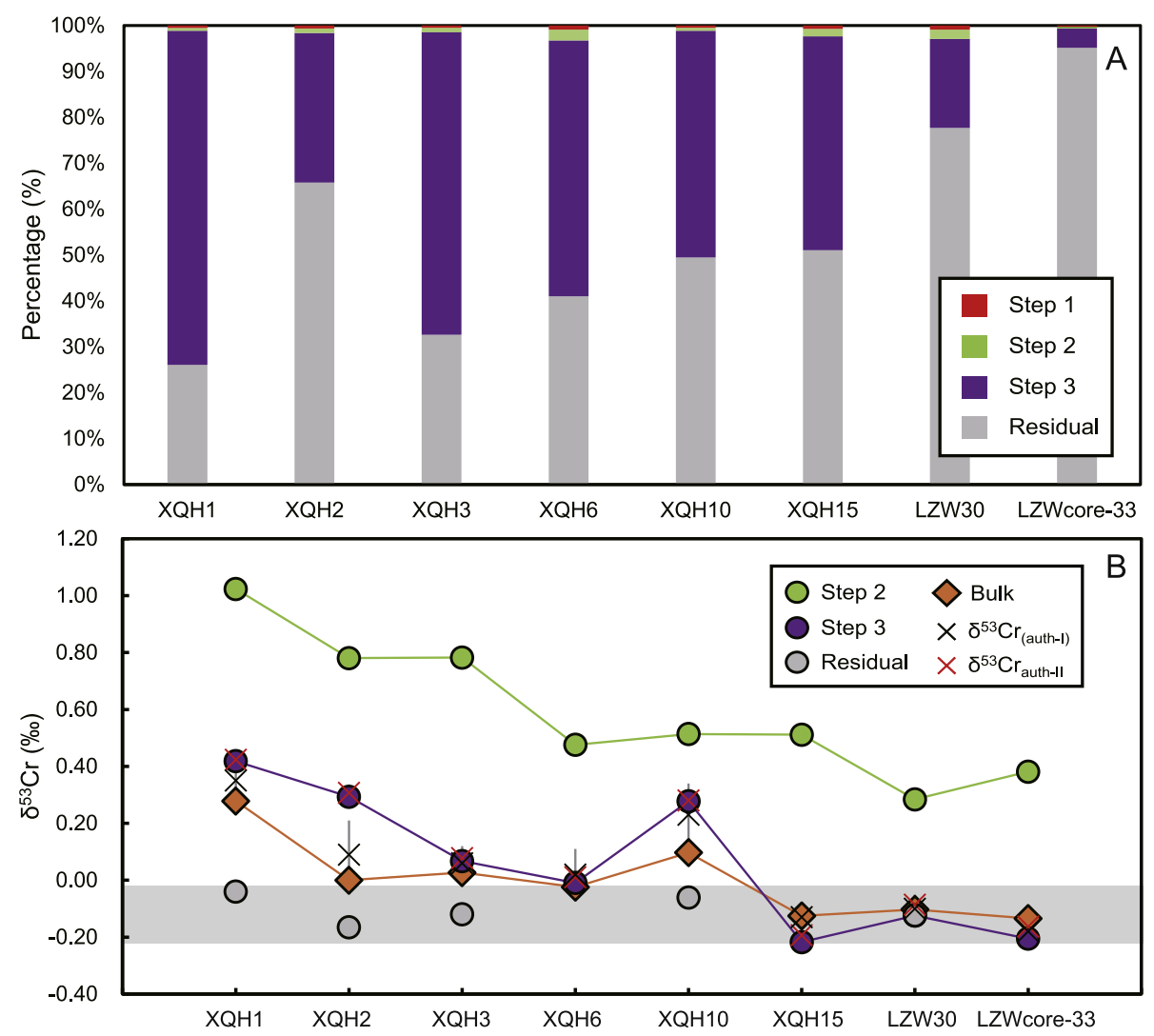

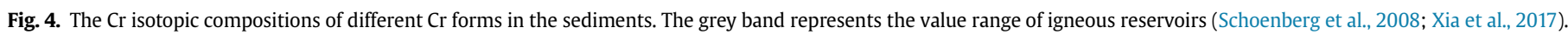

following formula described by Reinhard et al. (2014):

$[\mathrm{Cr}]_{\text {auth }-\mathrm{I}}=[\mathrm{Cr}]_{\text {total }}-\left([\mathrm{Ti}]_{\text {total }} \times[\mathrm{Cr} / \mathrm{Ti}]_{\mathrm{UCC}}\right)$,

$$
\delta^{53} \mathrm{Cr}_{\text {auth-I }}=\left(\delta^{53} \mathrm{Cr}_{\text {bulk }}-\left[\left(1-f_{\text {auth-I }}\right) \times \delta^{53} \mathrm{Cr}_{\text {det }}\right]\right)
$$

$$
\times f_{\text {auth"TT5843c571"'ADI }}{ }^{\text {"TT5843c571"'AD1, }}
$$

where $[\mathrm{Cr}]_{\text {auth-I }}$ is the authigenic $\mathrm{Cr}$ concentrations, $[\mathrm{Cr}]_{\text {total }}$ and $[\mathrm{Ti}]_{\text {total }}$ are the measured whole-rock $\mathrm{Cr}$ and $\mathrm{Ti}$ concentrations, respectively, and $[\mathrm{Cr} / \mathrm{Ti}]_{\mathrm{UCC}}$ is the $\mathrm{Cr} / \mathrm{Ti}$ ratio of the upper continental crust (0.024; Rudnick and Gao, 2003). $\delta^{53} \mathrm{Cr}_{\text {bulk }}$ is the bulk $\mathrm{Cr}$ isotopic composition that we measured, $\delta^{53} \mathrm{Cr}_{\text {det }}$ represents the mean $\mathrm{Cr}$ isotopic composition of the detrital component which is $-0.12 \%$ (Schoenberg et al., 2008), and $f_{\text {auth-I }}$ denotes the authigenic fraction of $\mathrm{Cr}\left(f_{\text {auth-I }}=[\mathrm{Cr}]_{\text {auth-I }} /[\mathrm{Cr}]_{\text {total }}\right)$. The uncertainties (2SD auth-I $)$ of $\delta^{53} \mathrm{Cr}_{\text {auth-I }}$ is propagated error according to Eqs. (2) and (3). The detrital contributions to the $\mathrm{Cr}$ in the four samples (XQH15, $\mathrm{XQH17}, \mathrm{XQH} 18$, and LZW30) from the downstream and estuary are too high, leading to significant corrections and large uncertainties in $\delta^{53} \mathrm{Cr}_{\text {auth-I }}$ for these samples relative to other samples (Fig. 3B). The corrected isotopic compositions showed that $\delta^{53} \mathrm{Cr}_{\text {auth-I }}$ of the sample $(\mathrm{XQH} 1)$ near the pollution source is the most positive, and $\delta^{53} \mathrm{Cr}_{\text {auth-I }}$ values decease in the midstream portion of the river to values between $0.00 \pm 0.08 \%$ to $0.02 \pm 0.09 \%$ (Fig. 3B).

\subsubsection{The authigenic Cr isotopic compositions ( $\left.\delta^{53} C r_{\text {auth-II }}\right)$ calculated using the BCR leaching procedure}

The modified BCR extraction procedure is operationally defined and the reagent used at each step is intended to release metals associated with particular phases. The nominal target phases are soil solutions, carbonates, and exchangeable metals in Step 1, Fe/Mn oxides/oxyhydroxides in Step 2, organic matter and sulfides in Step 3, and the residual (Žemberyová et al., 2006). Chromium in Step 1, 2 , and 3 are considered as the authigenic $\mathrm{Cr}$. The fraction of the Step 1 is very small and it is difficult to perform $\mathrm{Cr}$ isotope analysis. Excluding this fraction does not affect the results. Thus, the $\delta^{53} \mathrm{Cr}_{\text {auth-II }}$ value is the weighted average of $\delta^{53} \mathrm{Cr}_{\text {Step } 2}$ and $\delta^{53} \mathrm{Cr}_{\text {Step }}$ 
3. Since the fraction of Step 2 is relatively small, the $\delta^{53} \mathrm{Cr}_{\text {auth-II }}$ value is close to the $\delta^{53} \mathrm{Cr}_{\text {Step } 3}$ values (Fig. 4). There is a similar tendency for the authigenic $\mathrm{Cr}$ isotopic compositions obtained using the two different approaches (Figs. 3 and 4).

\subsection{The different sources of $\mathrm{Cr}$ identified from $\mathrm{Cr}$ isotopic signature}

The authigenic $\mathrm{Cr}$ in the sediments comes not only from the anthropogenic discharge but also from oxidative chemical weathering processes. Previous studies of weathering profiles showed that the heavy $\mathrm{Cr}$ isotopes are depleted in the weathering residues (Berger and Frei, 2014; Frei et al., 2014). Frei et al. (2014) found that there is limited $\mathrm{Cr}$ isotopic variation in the water samples from the Paraná River at NW Argentina. Compared to that site, the drainage basin of the Xiaoqing River is much smaller, and the overlying rocks in the catchment should be simpler. Thus, the $\mathrm{Cr}$ in the river water from oxidative chemical weathering processes in the area should has homogeneous isotopic composition. Although the variation of dissolved $\delta^{53} \mathrm{Cr}$ from the Connecticut River estuary was larger than $1 \%$, possibly as a result of $\mathrm{Cr}$ release from particles to solution during the transition from brackish to salt water, the particulate $\delta^{53} \mathrm{Cr}$ remained stable at about $0.1 \%$ (Sun et al., 2019). The suspended $\delta^{53} \mathrm{Cr}$ of the whole Connecticut River also varied little (Wu et al., 2017), indicating that the $\delta^{53} \mathrm{Cr}$ values of sediments which have more detritus portion than particulate should also be homogeneous when there is no anthropogenic discharge. The authigenic $\mathrm{Cr}$ in the sediments mainly comes from the reduction of $\mathrm{Cr}(\mathrm{VI})$ in river water, and the organic matters are common electron donors and can reduce $\mathrm{Cr}(\mathrm{VI})$ effectively (e.g. Kitchen et al., 2012; Sillerová et al., 2014). The plots of $\delta^{53} \mathrm{Cr}_{(\text {auth-I) }}$ versus TOC (Fig. 5B) show that $\mathrm{Cr}$ isotopic compositions do not vary with TOC except for samples $\mathrm{XQH} 1$ and $\mathrm{XQH} 10$, which may be influenced by anthropogenic discharge. The $\delta^{53} \mathrm{Cr}_{\text {auth-II }}$ values of sample XQH1 and XQH10 are $0.42 \pm 0.03 \%$ and $0.31 \pm 0.03 \%$, which are similar to the $\delta^{53} \mathrm{Cr}_{\text {auth-I }}$ values $(0.35 \pm 0.06 \%$ and $0.23 \pm 0.11 \%$, respectively). However, for $\mathrm{XQH} 2$, the $\delta^{53} \mathrm{Cr}_{\text {auth-II }}$ value $(0.31 \pm 0.03 \%$ ) is more positive than the $\delta^{53} \mathrm{Cr}_{\text {auth-I }}$ value $(0.09 \pm 0.12 \%$ ) (Fig. $5 \mathrm{C})$. The lower concentration of $\mathrm{Cr}_{\text {auth-I }}$ leads to the imprecise determination of authigenic $\mathrm{Cr}$ isotopic composition using $\mathrm{Cr} / \mathrm{Ti}$ index. Thus, our $\mathrm{Cr}$ isotopic result showed that the sampling site of $\mathrm{XQH} 2$ still suffers from anthropogenic discharge, but the $\mathrm{Cr}$ concentration from pollution is low.

The $\mathrm{Cr}$ concentration for sample $\mathrm{XQH3}$ is even higher than sample $\mathrm{XQH} 1$ while the Ti concentration for $\mathrm{XQH} 3$ is also higher than other samples, leading to slightly lower $\mathrm{Cr} / \mathrm{Ti}$ than that of XQH1 (Fig. 5A). Both samples have high $\mathrm{Cr} / \mathrm{Ti}$, however, the $\delta^{53} \mathrm{Cr}$ values are quite different, indicating the addition of reduction product of $\mathrm{Cr}(\mathrm{VI})$ from anthropogenic discharge to $\mathrm{XQH} 1$, resulting in the positive $\delta^{53} \mathrm{Cr}$ value in XQH1. The high $\mathrm{Cr} / \mathrm{Ti}$ and low $\delta^{53} \mathrm{Cr}$ value in $\mathrm{XQH} 3$ may result from oxidative chemical weathering products which have relatively low $\delta^{53} \mathrm{Cr}$ values. Similarly, we suggest that the $\mathrm{Cr}$ isotopic compositions of midstream and downstream samples are resulted from mixing between oxidative chemical weathering and detritus. For sample XQH10 from the tributary, the $\delta^{53} \mathrm{Cr}_{\text {auth }}$ value is more positive than other samples from the midstream sites, indicative of the influence of anthropogenic discharge. This conclusion is supported by the existence of an industrial district in the vicinity of the sampling location of XQH10.

For the $\mathrm{Fe}-\mathrm{Mn}$-oxide-bound $\mathrm{Cr}$, the $\mathrm{Cr}$ isotopic compositions are more positive than other leaching parts and there is a more obvious decreasing tendency from upstream to downstream (Fig. 4). Previous studies showed that the $\mathrm{Cr}$ isotopic compositions of marine ferromanganese oxides are negative than the seawater, probably because the Mn-oxides preferentially adsorb the lighter $\mathrm{Cr}$ isotopes (Wei et al., 2018), and there is no obvious $\mathrm{Cr}$ isotopic fractionation during $\mathrm{Cr}(\mathrm{VI})$ sorption on goethite at equilibrium (Ellis et al., 2004).
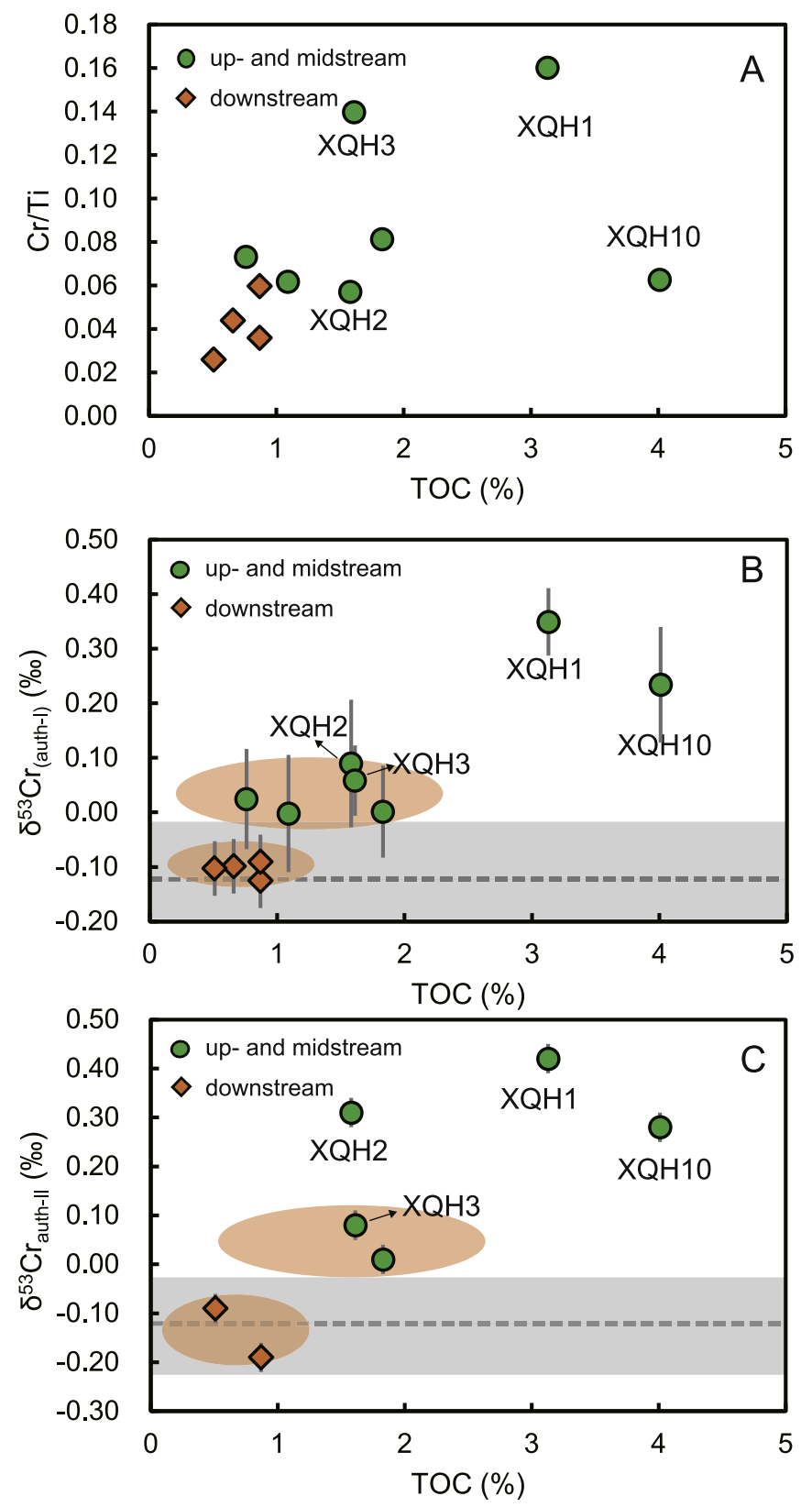

Fig. 5. TOC versus $\mathrm{Cr} / \mathrm{Ti}(\mathrm{A}), \delta^{53} \mathrm{Cr}_{(\text {auth-l) }}(\mathrm{B})$, and $\delta^{53} \mathrm{Cr}_{\text {auth-II }}(\mathrm{C})$ for surface sediment samples from the Xiaoqing River. The TOC data are from He et al. (2018). The green circles refer the $\delta^{53} \mathrm{Cr}_{\text {auth }}$ values for upstream and midstream samples and the orange diamonds refer the bulk $\delta^{53} \mathrm{Cr}$ values for downstream samples which cannot be calculated due to the significant detrital contributions. The $2 \mathrm{SD}_{\text {auth-I }}(\mathrm{B})$ of downstream samples is large, thus we use $\delta^{53} \mathrm{Cr}_{\text {bulk }}$ (orange diamonds) instead. The grey band represents the value range of igneous reservoirs (Schoenberg et al., 2008; Xia et al., 2017) and the dashed line represents the median of the range. (For interpretation of the references to colour in this figure legend, the reader is referred to the Web version of this article.)

The Mn concentration in the extracting solution is much lower than the Fe concentration (Table S2), thus the Fe-Mn-oxide-bound $\mathrm{Cr}$ obtained in Step 2 is mainly from the Fe oxides. Therefore, $\delta^{53} \mathrm{Cr}$ values of this fraction might more or less record the $\delta^{53} \mathrm{Cr}$ values of the river water. The decreasing tendency suggests that this part of $\mathrm{Cr}$ should not solely come from the oxidative chemical weathering, because the $\delta^{53} \mathrm{Cr}$ values of the river water without pollution have an increasing tendency from the upstream to the estuary (D'Arcy et al., 2016). More likely, it suggests a mixing between 
anthropogenic discharge and natural weathering.

For the sedimentary core samples from Laizhou Bay, the $\delta^{53} \mathrm{Cr}_{\text {bulk }}$ values are similar to the average value of igneous reservoirs indicating that $\mathrm{Cr}$ mainly comes from detritus. The residual $\mathrm{Cr}$ isotopic compositions of all 5 selected samples lie in the range of igneous reservoirs, further indicative of a detrital component. This also shows the effectiveness of the BCR leaching experiment. The $\mathrm{Cr}$ concentrations (58-73 ppm) for the samples from Laizhou Bay are lower than the primary sediment criteria $(80 \mathrm{ppm})$ of Marine Sediment Quality (GB 18668-2002) issued by the China State Bureau of Quality and Technical Supervision (CSBTS, 2002). The low $\mathrm{Cr}$ concentrations and negative $\delta^{53} \mathrm{Cr}$ values show that there is no obvious $\mathrm{Cr}$ pollution in Laizhou Bay, and the limited variation in the sediment core with depth is also indicative of no obvious $\mathrm{Cr}$ pollution in Laizhou Bay in the history. Overall, similar conclusions on the source of $\mathrm{Cr}$ can be drawn based on the authigenic $\mathrm{Cr}$ isotopic compositions calculated with the detrital index and using the BCR leaching protocol.

\subsection{The quantification of in situ $\mathrm{Cr}(\mathrm{VI})$ reduction}

Chromium isotopes can be used to evaluate the extent of $\mathrm{Cr}(\mathrm{VI})$ reduction in groundwater (e.g. Berna et al., 2010; Izbicki et al., 2008). Here, we use $\mathrm{Cr}$ isotopes to estimate the degree of $\mathrm{Cr}(\mathrm{VI})$ reduction on the basis of the Rayleigh fractionation model. It is generally believed that the $\mathrm{Cr}$ isotopic fractionation will follow the Rayleigh fractionation model if the $\mathrm{Cr}(\mathrm{VI})$ reduction takes place in a closed system, the $\operatorname{Cr}(\mathrm{VI})$ concentration is homogeneous in the solution, the reduction product $\mathrm{Cr}$ (III) is removed from the system immediately, and the kinetic fractionation factor remains constant. In a river system, we focus on the water mass with contamination. It is assumed that once the water mass flows away from the factories, no further $\mathrm{Cr}$ contamination is added to it. The reduction product $\mathrm{Cr}$ (III) will precipitate into the sediment or get adsorbed by particles immediately because of its low solubility. In addition, the kinetic fractionation factor is almost invariant due to the similar water environment along the Xiaoqing River. The Rayleigh fractionation model is expressed as

$\delta^{53} \mathrm{Cr}=\left[\left(\delta^{53} \mathrm{Cr}_{\text {ini }}+10^{3}\right) f^{(\alpha-1)}\right]-10^{3}$,

where $\delta^{53} \mathrm{Cr}_{\text {ini }}$ is the $\delta^{53} \mathrm{Cr}$ value of the initial anthropogenic source, $f$ is the fraction of remaining $\operatorname{Cr}(\mathrm{VI})$, and $\alpha$ is the fractionation factor ( $\alpha=\mathrm{R}_{\text {reactant }} / \mathrm{R}_{\text {product }}$ ), which can be expressed in terms of the isotopic enrichment factor $\varepsilon$ as:

$\varepsilon=(\alpha-1) \times 1000$,

where $\varepsilon$ is approximately the difference in $\delta^{53} \mathrm{Cr}$ values between the reactant and the product.

$\varepsilon \approx \delta^{53} \mathrm{Cr}_{\text {rea }}-\delta^{53} \mathrm{Cr}_{\text {pro }}$.

According to previous work, the value of $\varepsilon$ obtained in laboratory conditions ranges from $0.2 \%$ to $5 \%$, and most of the results are in the range of $2 \%-4 \%$ (e.g. Chen et al., 2019b; Ellis et al., 2002; Berna et al., 2010; Jamieson-Hanes et al., 2012a; Jamieson-Hanes et al., 2012b; Qin and Wang, 2017; Zink et al., 2010). However, because of the reservoir effects in a natural system, a smaller "effective" enrichment factor, $\varepsilon_{\text {eff }}$ should be applied (Berna et al., 2010; Clark and Johnson, 2008). The studies of river sediments are lacking but the $\mathrm{Cr}(\mathrm{VI})$ reduction experiments with the natural groundwater sediments had been conducted (Berna et al., 2010). As these two kinds of sediments have similar components, here we use the $\varepsilon_{\text {eff }}$ value of $1.37 \%$ estimated from groundwater sediments in Berna et al. (2010).

The calculated $\delta^{53} \mathrm{Cr}_{\text {auth-I }}$ value for sample $\mathrm{XQH} 1$ is $0.35 \%$ and the $\delta^{53} \mathrm{Cr}_{\text {auth-II }}$ value is $0.42 \%$. However, the $\mathrm{Fe}-\mathrm{Mn}$-oxide-bound $\mathrm{Cr}$ probably contains the absorbed $\mathrm{Cr}(\mathrm{VI})$, not only the reduced product, and the leaching experiment can give a more accurate value, thus the $\delta^{53} \mathrm{Cr}_{\text {Step } 3}$ value $(0.42 \%$ ) is used here to represent the instantaneous reduction product of the remaining $\mathrm{Cr}(\mathrm{VI})$ from the anthropogenic discharge at this site. We note that this value also includes the contribution from oxidative weathering. The mean value of $\delta^{53} \mathrm{Cr}_{\text {auth-I }}$ for the three midstream samples (sample $\mathrm{XQH5}, \mathrm{XQH6}$, and $\mathrm{XQH7}$ ) which represent the contribution from oxidative weathering is $0.01 \%$, very close to zero. The $\delta^{53} \mathrm{Cr}_{\text {auth-II }}$ value for sample XQH6 is $0.01 \%$, consistent with the $\delta^{53} \mathrm{Cr}_{\text {auth-I }}$ value. Because oxidative weathering is prevailing everywhere and we are interested in mainly the reduction of anthropogenic $\mathrm{Cr}$, we neglect the contribution from oxidative weathering and estimate the lower limit on the reduction extent. According to Eq. (6), the lower limit of $\delta^{53} \mathrm{Cr}$ value for the remaining $\mathrm{Cr}(\mathrm{VI})$ from the anthropogenic discharge in the river water at the sampling site of $\mathrm{XQH} 1$ is $1.79 \%$. The $\delta^{53} \mathrm{Cr}$ values for the solution in the plating bath is between $0.20 \%$ and $0.83 \%$ (Berna et al., 2010; Ellis et al., 2002; Novak et al., 2017), and the chromating bath is also lying in this range (Novak et al., 2017). Thus, this range is used as the $\delta^{53} \mathrm{Cr}$ values for the pollution source. Based on the Rayleigh fractionation model, we calculate that $f$ is $31 \%-50 \%$. Namely, during the transportation of $\mathrm{Cr}(\mathrm{VI})$ from the source to the site of $\mathrm{XQH} 1$, at least $31 \%$ $50 \%$ of $\mathrm{Cr}(\mathrm{VI})$ had been reduced to $\mathrm{Cr}(\mathrm{III})$. Using the same calculation method, at least $34 \%-55 \%$ of $\mathrm{Cr}(\mathrm{VI})$ at the site of $\mathrm{XQH} 2$ had been reduced to $\mathrm{Cr}(\mathrm{III})$. Similarly, the $\delta^{53} \mathrm{Cr}_{\text {Step }} 3$ value of the tributary sample XQH10 is $0.28 \%$, and a reduction of $35 \%-55 \%$ of the $\mathrm{Cr}(\mathrm{VI})$ can be calculated at that sampling location.

\section{Conclusions}

The $\mathrm{Cr}$ isotopic compositions in the sediments facilitate the identification of different $\mathrm{Cr}$ sources in the Xiaoqing River. Based on the calculation of authigenic $\mathrm{Cr}$ isotopic compositions using the detrital index and leaching experiments, we found that the most positive $\delta^{53} \mathrm{Cr}$ value near the pollution source of the Xiaoqing River was influenced by anthropogenic discharge of $\mathrm{Cr}(\mathrm{VI})$. Due to the self-purification of river water, this signal was not recorded in sediments from downstream sampling sites. Using a Rayleigh model for isotopic fractionation, we estimated that at least $31 \%-$ $55 \%$ of $\mathrm{Cr}(\mathrm{VI})$ in the river water near the pollution source was reduced to $\mathrm{Cr}(\mathrm{III})$. Combining with $\mathrm{Cr} / \mathrm{Ti}$ and $\mathrm{TOC}$, we suggest that the slightly positive $\delta^{53} \mathrm{Cr}$ values in the midstream mostly represent the signal from oxidative weathering, and the $\delta^{53} \mathrm{Cr}$ values in the range of igneous reservoirs for the sediments near the estuary and in Laizhou Bay indicate that the $\mathrm{Cr}$ mainly comes from detritus. Similarly, the limited variation of $\delta^{53} \mathrm{Cr}$ values for the sedimentary core samples in Laizhou Bay reveals no $\mathrm{Cr}$ pollution in history.

\section{Declaration of competing interests}

The authors declare that they have no known competing financial interests or personal relationships that could have appeared to influence the work reported in this paper.

\section{CRediT authorship contribution statement}

Xiaoqing He: Investigation, Methodology, Writing - original draft. Guojun Chen: Resources. Ziyao Fang: Formal analysis, Writing - review \& editing. Wenjian Liang: Investigation. Boda Li: Investigation. Jianhui Tang: Resources, Writing - review \& editing. Yongge Sun: Writing - review \& editing. Liping Qin: 
Conceptualization, Supervision, Writing - review \& editing.

\section{Acknowledgments}

We thank Jia Liu, Qun Zhang, Yingnan Zhang and Huimin Yu for MC-ICP-MS and TIMS support; and Ji Shen and David L. Cook for discussions. This work was funded by B-type Strategic Priority Program of the Chinese Academy of Sciences, China (Grant No. XDB41000000), National Natural Science Foundation of China, China (41625013, 41721002, 41888101), the PreresearchProjecton Civil Aerospace Technologies (D020202) of Chinese National Space Administration, China and the Fundamental Research Funds for the Central Universities of China, China (WK2080000102).

\section{Appendix A. Supplementary data}

Supplementary data to this article can be found online at https://doi.org/10.1016/j.envpol.2020.114686.

\section{References}

Berger, A., Frei, R., 2014. The fate of chromium during tropical weathering: a laterite profile from Central Madagascar. Geoderma 213, 521-532.

Berna, E.C., Johnson, T.M., Makdisi, R.S., Basui, A., 2010. Cr stable isotopes as indicators of $\mathrm{Cr}(\mathrm{VI})$ reduction in groundwater: a detailed time-series study of a point-source plume. Environ. Sci. Technol. 44, 1043-1048.

Bonnand, P., Parkinson, I.J., Anand, M., 2016. Mass dependent fractionation of stable chromium isotopes in mare basalts: implications for the formation and the differentiation of the Moon. Geochem. Cosmochim. Acta 175, 208-221.

Chen, G., Han, J., Mu, Y., Yu, H., Qin, L., 2019a. Two-stage chromium isotope fractionation during microbial $\mathrm{Cr}$ (VI) reduction. Water Res. 148, 10-18.

Chen, G., Bai, Y., Zeng, R.J., Qin, L., 2019b. Effects of different metabolic pathways and environmental parameters on $\mathrm{Cr}$ isotope fractionation during $\mathrm{Cr}(\mathrm{VI})$ reduction by extremely thermophilic bacteria. Geochem. Cosmochim. Acta 256, 135-146.

Clark, S.K., Johnson, T.M., 2008. Effective isotopic fractionation factors for solute removal by reactive sediments: a laboratory microcosm and slurry study. Environ. Sci. Technol. 42, 7850-7855.

CSBTS (China State Bureau of Quality and Technical Supervision), 2002. Marine Sediment Quality. Standards Press of China, Beijing, China, p. 10 (in Chinese).

D’Arcy, J., Babechuk, M.G., Døssing, L.N., Gaucher, C., Frei, R., 2016. Processes controlling the chromium isotopic composition of river water: constraints from basaltic river catchments. Geochem. Cosmochim. Acta 186, 296-315.

Economou-Eliopoulos, M., Frei, R., Atsarou, C., 2014. Application of chromium stable isotopes to the evaluation of $\mathrm{Cr}(\mathrm{VI})$ contamination in groundwater and rock leachates from central Euboea and the Assopos basin (Greece). Catena 122, 216-228.

Ellis, A.S., Johnson, T.M., Bullen, T.D., 2002. Chromium isotopes and the fate of hexavalent chromium in the environment. Science 295, 2060-2062.

Ellis, A.S., Johnson, T.M., Bullen, T.D., 2004. Using chromium stable isotope ratios to quantify $\mathrm{Cr}$ (VI) reduction: lack of sorption effects. Environ. Sci. Technol. 38 $3604-3607$.

Farkaš, J., Chrastný, V., Novák, M., Čadkova, E., Pašava, J., Chakrabarti, R. Jacobsen, S.B., Ackerman, L., Bullen, T.D., 2013. Chromium isotope variations $(\delta 53 / 52 \mathrm{Cr})$ in mantle-derived sources and their weathering products: implications for environmental studies and the evolution of $853 / 52 \mathrm{Cr}$ in the Earth's mantle over geologic time. Geochem. Cosmochim. Acta 123, 74-92.

Fendorf, S.E., 1995. Surface reactions of chromium in soils and waters. Geoderma 67, $55-71$

Frei, R., Poiré, D., Frei, K.M., 2014. Weathering on land and transport of chromium to the ocean in a subtropical region (Misiones, NW Argentina): a chromium stable isotope perspective. Chem. Geol. 381, 110-124.

Goring-Harford, H.J., Klar, J.K., Donald, H.K., Pearce, C.R., Connelly, D.P., James, R.H., 2020. Behaviour of chromium and chromium isotopes during estuarine mixing in the Beaulieu Estuary, UK. Earth Planet Sci. Lett. 536, 116166.

He, D., Zhang, K., Cui, Q., Tang, J., Sun, Y., 2018. Spatiotemporal variability of hydrocarbons in surface sediments from an intensively human-impacted Xiaoqing River-Laizhou Bay system in the eastern China: occurrence, compositional profile and source apportionment. Sci. Total Environ. 645, 1172-1182.

Heikoop, J.M., Johnson, T.M., Birdsell, K.H., Longmire, P., Hickmott, D.D., Jacobs, E.P., Broxton, D.E., Katzman, D., Vesselinov, V.V., Ding, M., Vaniman, D.T., Reneau, S.L. Goering, T.J., Glessner, J., Basu, A., 2014. Isotopic evidence for reduction of anthropogenic hexavalent chromium in Los Alamos National Laboratory groundwater. Chem. Geol. 373, 1-9.

Heydebreck, F., Tang, J., Xie, Z., Ebinghaus, R., 2015. Alternative and legacy perfluoroalkyl substances: differences between European and Chinese river/estuary systems. Environ. Sci. Technol. 49, 8386-8395.

Izbicki, J.A., Ball, J.W., Bullen, T.D., Sutley, S.J., 2008. Chromium, chromium isotopes and selected trace elements, western Mojave Desert, USA. Appl. Geochem. 23, $1325-1352$.

Izbicki, J.A., Bullen, T.D., Martin, P., Schroth, B., 2012. Delta Chromium-53/52 isotopic composition of native and contaminated groundwater, Mojave Desert, USA. Appl. Geochem. 27, 841-853.

Jamieson-Hanes, J.H., Amos, R.T., Blowes, D.W., 2012a. Reactive transport modeling of chromium isotope fractionation during $\mathrm{Cr}(\mathrm{VI})$ reduction. Environ. Sci. Technol. 46, 13311-13316.

Jamieson-Hanes, J.H., Gibson, B., Lindsay, M., Kim, Y., Ptacek, C., Blowes, D., 2012b. Chromium isotope fractionation during reduction of $\mathrm{Cr}(\mathrm{VI})$ under saturated flow conditions. Environ. Sci. Technol. 46, 6783-6789.

Jiang, T., Skyllberg, U., Björn, E., Green, N.W., Tang, J., Wang, D., Gao, J., Li, C., 2017. Characteristics of dissolved organic matter (DOM) and its relationship with dissolved mercury in Xiaoqing River-Laizhou Bay estuary, Bohai Sea, China. Environ. Pollut. 223, 19-30.

Johnson, T.M., Bullen, T.D., 2004. Mass-dependent fractionation of selenium and chromium isotopes in low-temperature environments. In: Johnson, C.M., Beard, B.L., Albarede, F. (Eds.), Geochemistry of Non-traditional Stable Isotopes Reviews in Mineralogy \& Geochemistry, vol. 55, pp. 289-317.

Kitchen, J.W., Johnson, T.M., Bullen, T.D., Zhu, J., Raddatz, A., 2012. Chromium isotope fractionation factors for reduction of $\mathrm{Cr}$ (VI) by aqueous $\mathrm{Fe}$ (II) and organic molecules. Geochem. Cosmochim. Acta 89, 190-201.

Konhauser, K.O., Lalonde, S.V., Planavsky, N.J., Pecoits, E., Lyons, T.W., Mojzsis, S.J. Rouxel, O.J., Barley, M.E., Rosìere, C., Fralick, P.W., Kump, L.R., 2011. Aerobic bacterial pyrite oxidation and acid rock drainage during the Great Oxidation Event. Nature 478 (7369), 369.

Miretzky, P., Cirelli, A.F., 2010. Cr (VI) and Cr (III) removal from aqueous solution by raw and modified lignocellulosic materials: a review. J. Hazard Mater. 180, 1-19.

Novak, M., Chrastny, V., Cadkova, E., Farkas, J., Bullen, T.D., Tylcer, J., Szurmanova, Z., Cron, M., Prechova, E., Curik, J., Stepanova, M., Pasava, J., Erbanova, L., Houskova, M., Puncochar, K., Hellerich, L.A., 2014. Common occurrence of a positive delta53Cr shift in Central European waters contaminated by geogenic/ industrial chromium relative to source values. Environ. Sci. Technol. 48, 6089-6096.

Novak, M., Chrastny, V., Sebek, O., Martinkova, E., Prechova, E., Curik, J., Veselovsky, F., Stepanova, M., Dousova, B., Buzek, F., Farkas, J., Andronikov, A., Cimova, N., Houskova, M., 2017. Chromium isotope fractionations resulting from electroplating, chromating and anodizing: implications for groundwater pollution studies. Appl. Geochem. 80, 134-142.

Paulukat, C., Døssing, L.N., Mondal, S.K., Voegelin, A.R., Frei, R., 2015. Oxidative release of chromium from Archean ultramafic rocks, its transport and environmental impact - $\mathrm{a} \mathrm{Cr}$ isotope perspective on the Sukinda valley ore district (Orissa, India). Appl. Geochem. 59, 125-138.

Qin, L., Wang, X., 2017. Chromium isotope geochemistry. Rev. Mineral. Geochem. 82, $379-414$.

Qin, L., Alexander, C.M.O.D., Carlson, R.W., Horan, M.F., Yokoyama, T., 2010. Contributors to chromium isotope variation of meteorites. Geochem. Cosmochim. Acta $74,1122-1145$

Raddatz, A.L., Johnson, T.M., McLing, T.L., 2010. Cr stable isotopes in Snake River Plain Aquifer groundwater: evidence for natural reduction of dissolved $\mathrm{Cr}(\mathrm{VI})$. Environ. Sci. Technol. 45, 502-507.

Rauret, G., LoÂpez-SaÂnchez, J.-F., Sahuquillo, A., Barahona, E., Lachica, M., Ure, A.M., Davidson, C.M., Gomez, A., LuËck, D., Bacon, J., Yli-Halla, M., Muntaub, H., Quevauviller, Ph, 2000. Application of a modified BCR sequential extraction (three-step) procedure for the determination of extractable trace metal contents in a sewage sludge amended soil reference material (CRM 483), complemented by a three-year stability study of acetic acid and EDTA extractable metal content. J. Environ. Monit. 2, 228-233.

Reinhard, C.T., Planavsky, N.J., Wang, X., Fischer, W.W., Johnson, T.M., Lyons, T.W., 2014. The isotopic composition of authigenic chromium in anoxic marine sediments: a case study from the Cariaco Basin. Earth Planet Sci. Lett. 407, 9-18.

Rudnick, R., Gao, S., 2003. Composition of the continental crust. Treatise on geochemistry 3, 659 .

Schauble, E., Rossman, G.R., Taylor, H.P., 2004. Theoretical estimates of equilibrium chromium-isotope fractionations. Chem. Geol. 205, 99-114.

Schoenberg, R., Zink, S., Staubwasser, M., von Blanckenburg, F., 2008. The stable $\mathrm{Cr}_{\mathrm{r}}$ isotope inventory of solid Earth reservoirs determined by double spike MC-ICPMS. Chem. Geol. 249, 294-306.

Shen, J., Liu, J., Qin, L., Wang, S.J., Li, S., Xia, J., Ke, S., Yang, J., 2015. Chromium isotope signature during continental crust subduction recorded in metamorphic rocks. G-cubed 16, 3840-3854.

Shen, J., Qin, L., Fang, Z., Zhang, Y., Liu, J., Liu, W., Wang, F., Xiao, Y., Yu, H., Wei, S. 2018. High-temperature inter-mineral $\mathrm{Cr}$ isotope fractionation: a comparison of ionic model predictions and experimental investigations of mantle xenoliths from the North China Craton. Earth Planet Sci. Lett. 499, 278-290.

Sikora, E.R., Johnson, T.M., Bullen, T.D., 2008. Microbial mass-dependent fractionation of chromium isotopes. Geochem. Cosmochim. Acta 72 (15), 3631-3641.

Šillerová, H., Chrastný, V., Čadková, E., Komárek, M., 2014. Isotope fractionation and spectroscopic analysis as an evidence of $\mathrm{Cr}(\mathrm{VI})$ reduction during biosorption. Chemosphere 95, 402-407.

Sun, Z., Wang, X., Planavsky, N., 2019. Cr isotope systematics in the Connecticut River estuary. Chem. Geol. 506, 29-39.

Testa, S.M., Guertin, J., Jacobs, J.A., Avakian, C.P., 2004. Sources of Chromium Contamination in Soil and Groundwater. CRC Press, Boca Raton, FL, pp. 143-163, $143-164$. 
Ure, A., Quevauviller, Ph, Muntau, H., Griepink, B., 1993. EUR Report, 14763 EN. European Commission, Brussels.

Wang, X., Planavsky, N.J., Reinhard, C.T., Zou, H., Ague, J.J., Wu, Y., Gill, B.C. Schwarzenbach, E.M., Peucker-Ehrenbrink, B., 2016. Chromium isotope fractionation during subduction-related metamorphism, black shale weathering, and hydrothermal alteration. Chem. Geol. 423, 19-33.

Wanner, C., Eggenberger, U., Kurz, D., Zink, S., Mäder, U., 2012. A chromatecontaminated site in southern Switzerland - Part 1: site characterization and the use of $\mathrm{Cr}$ isotopes to delineate fate and transport. Appl. Geochem. 27, 644-654.

Wei, W., Frei, R., Chen, T., Klaebe, R., Liu, H., Li, D., Wei, G., Ling, H., 2018. Marine ferromanganese oxide: a potentially important sink of light chromium isotopes? Chem. Geol. 495, 90-103.

Wu, W., Wang, X., Reinhard, C.T., Planavsky, N.J., 2017. Chromium isotope systematics in the Connecticut River. Chem. Geol. 456, 98-111.

Xia, J., Qin, L., Shen, J., Carlson, R.W., Ionov, D.A., Mock, T.D., 2017. Chromium isotope heterogeneity in the mantle. Earth Planet Sci. Lett. 464, 103-115.

Žemberyová, M., Bartekova, J., Hagarova, I., 2006. The utilization of modified BCR three-step sequential extraction procedure for the fractionation of $\mathrm{Cd}, \mathrm{Cr}, \mathrm{Cu}, \mathrm{Ni}$, $\mathrm{Pb}$ and $\mathrm{Zn}$ in soil reference materials of different origins. Talanta 70, 973-978.

Zhen, X., Tang, J., Liu, L., Wang, X., Li, Y., Xie, Z.Y., 2018. From headwaters to estuary: distribution and fate of halogenated flame retardants (HFRs) in a river basin near the largest HFR manufacturing base in China. Sci. Total Environ. 621, 1370-1377.

Zink, S., Schoenberg, R., Staubwasser, M., 2010. Isotopic fractionation and reaction kinetics between $\mathrm{Cr}(\mathrm{III})$ and $\mathrm{Cr}(\mathrm{VI})$ in aqueous media. Geochem. Cosmochim. Acta $74,5729-5745$. 